\title{
Development of Islamic Education Curriculum Model Curriculum 2013 (K13)
}

\author{
* Dwi Noviatul Zahra \\ (Universitas Islam Negeri (UIN) Sunan Kalijaga, Jl. Laksda Adisucipto, Papringan, \\ Caturtunggal, Depok, Kabupaten Sleman, Yogyakarta) \\ *dwinoviatulzahra11@gmail.com
}

\begin{abstract}
The development of an Islamic religious education curriculum (PAI) is an activity to produce a PAI curriculum and a process that links one component to another to create a better Islamic education curriculum (PAI). The curriculum component must consist of at least four parts, namely objectives, contents, processes and assessments. This study discusses in depth the development of the curriculum in the Indonesian curriculum for the 2013 Curriculum model. This study aims to determine the extent to which the curriculum development curriculum for the 2013 curriculum model PAI. This study uses a literature review method. Data collection is done through documentation study techniques. The results of this study indicate that the curriculum development of the 2013 curriculum in the PAI is very significant, oriented towards realising character education, creating education with local insight and creating a cheerful and friendly culture.
\end{abstract}

Pengembangan kurikulum Pendidikan Agama Islam (PAI) adalah kegiatan menghasilkan kurikulum PAI, dan proses yang mengkaitkan satu komponen dengan komponen yang lainya untuk menghasilkan kurikulum pendidikan agama Islam (PAI) yang lebih baik. Komponen kurikulum setidaknya harus terdiri dari empat komponen yaitu tujuan, isi, proses dan penilaian. Penelitian ini membahas secara mendalam mengenai pengembangan kurikulum PAI model Kurikulum 2013. Penelitian ini bertujuan untuk mengetahui sejauh mana pengembangan kurikulum PAI model Kurikulum 2013. Penelitian ini menggunakan metode kajian pustaka.Pengumpulan data dilakukan dengan teknik studi dokumentasi. Hasil penelitian ini menunjukkan pengembangan kurikulum PAI Kurikulum 2013 pada ranah ini sangat signifikan, yang berorientasi pada mewujudkan pendidikan berkarakter, menciptakan pendidikan berwawasan lokal serta menciptakan pendidikan yang ceria dan bersahabat.

Keywords: Curriculum Development, 2013 Curriculum Model.

Received: February 28, 2019; Revised: May 18, 2019; Accepted: June 12, 2019

\section{INTRODUCTION}

Education is still considered as one of the essential elements to be able to advance the life of the nation and the state. The role of education cannot be ignored to colour the development of human civilisation. When talking about education, it cannot be separated from discussing the curriculum. As well as a guide in the implementation of 
training. The curriculum reflects the life philosophy of the nation, the direction and purpose of life of a country (Nuraini, 2016). The presence of a nation wherever and whenever always experiences development, both social, political and economic. Social values, needs and demands of society tend to undergo changes caused by the advancement of science and technology. To anticipate this change, education is expected to be a solution, because so far, education is still considered as one of the most strategic ways to balance the progress of science and technology.

A curriculum is a tool or key in the formal education process. It is not surprising that this tool is always overhauled or revisited to keep abreast of science and times. The term development itself refers to an activity producing a new device or method, during which the assessment and improvement of the tool or way continue to be carried out to create the ideal curriculum to be applied (Wawan Kusnawan, 2019).

In a curriculum itself, various components or elements build the curriculum, and between one part and the other components are interrelated. If one component does not exist or does not function, it can be said that the curriculum failed or did not succeed. Therefore, to achieve a curriculum success, a sound system is needed that contains the best curriculum components and is supported by the best curriculum structure.

The 2013 curriculum had raised new hopes, namely the more attention to aspects of student attitudes (Nurhadi, 2018). This hope seems to cause fresh air for teachers of Islamic Religious Education (PAI), especially those that have always been in the spotlight for the moral decline of today's young generation (Afiful Ikhwan, 2017); (Musyarapah, 2017). This is because PAI teachers are considered the moral responsibility of students at school. This is normal considering the contents of PAI material that resembles noble values.

Islamic Education Curriculum (PAI) has a central position in the whole process of education, as a direction for all educational activities to achieve goals. Also, also as an educational plan, the curriculum is a guide and handle on the type, scope, and sequence of content and strategies of the education process. For this reason, the speakers will try to explain how to develop the K13 Islamic Education curriculum (PAI).

\section{DEFINITION OF ISLAMIC EDUCATION CURRICULUM DEVELOPMENT}

The definition of curriculum development consists of two words, namely "development" and "curriculum". The term development shows an activity or activity that produces a new tool or method, in which operations are carried out various improvements of something that is already in advance and finally the way or device that has been carried out during the activity will be chosen to be carried out or applied. While the understanding of the curriculum itself according to According to S. Nasution that curriculum is something that is planned as a handle to achieve educational goals (while in the National Education System Law No. 23 of 2003, stated that the curriculum is a set of plans and arrangements regarding the purpose, content, and teaching materials, as well as ways that are used as guidelines for teachers in conducting learning activities to achieve specific goals.

The curriculum is an essential element that cannot be ignored by its existence. Because without a curriculum, it is difficult for educational planners to achieve their educational goals. Etymologically, the curriculum comes from Greek, curlers, which means running and care which means a place to race (Abdullah Idi, 2007). 
Oemar Hamalik explained that the curriculum is an educational program provided by educational institutions (schools) for students. Based on the education program, students carry out various learning activities to encourage their development and growth by the educational objectives that have been applied. Hilda Taba the Begawan curriculum in Curriculum Development: Theory and Practice define curriculum as a plan for learning; therefore, what is known about the learning process and the development of individuals has a bearing on the shaping of a curriculum (Lili Hidayati, 2014).

From the two meanings of the word "development" and "curriculum" above, it gives rise to a new understanding that curriculum development is an activity to produce a new curriculum through steps in curriculum development on the basis of the results of assessments carried out over a period of time, and also means changes and tonal shifts from one curriculum to another curriculum, and this change takes place in a long time. Besides that, curriculum development can also be interpreted as a process that determines how curriculum development will work (Umar Ahmad Darwis, 2015).

Curriculum development is essentially a deliberate process or activity and is thought to produce a curriculum as a guide in the process and implementation of learning by teachers in schools. Curriculum development means directing the current curriculum to the expected educational goals because of the various positive influences that come from outside or from within themselves in the hope that students can face their future well (Dakir, 2010).

From this understanding it can be concluded that curriculum development refers to activities to produce curriculum, this activity is more conceptual than material, and what is meant in this development is arrangement, implementation, assessment and improvement, which subsequently provides a new curriculum as a result of the construction undertaken.

Islamic Education is a conscious and planned effort in preparing students to recognise, understand, appreciate and believe in the teachings of Islam, coupled with guidance to respect the adherents of other religions about the harmony between religious groups to the realisation of national unity and unity (a.Abdul Majid and Dian Andayani, 2005).

Whereas according to Zakiah Daradjat, Islamic Education is an effort to foster and nurture students so that they can always understand Islamic teachings as a whole and in the end can make Islam as a view of life (Zakiah Darajat, 2002). Whereas according to Tayar Yusuf Islamic religious education is interpreted as a conscious effort of the older generation to divert experience, knowledge, skills and skills to the younger generation so that later they become human beings fearing Allah (b.Abdul Majid and Dian Andayani, 2005.

The development of an Islamic religious education curriculum (PAI) is an activity that produces a PAI curriculum or process that links one component to another to create a better PAI curriculum and design (design) implementation of the PAI curriculum assessment and improvement (Muhaimin, 2005).

While the notion of developing an Islamic religious education curriculum (PAI) is an activity to produce a PAI curriculum and a process that links one component to another to provide better Islamic education (PAI) curriculum (Subandiah, 1993).

From the various meanings above, the development of the PAI curriculum is an activity to foster students to produce good curriculum in PAI and design activities for implementing the assessment and improvement of the PAI curriculum. 


\section{PURPOSE OF THE PAI CURRICULUM}

The use of Islamic education has differences with other educational goals, for example, the purpose of knowledge according to the understanding of pragmatism, which focuses on the utilisation of human life in the world. The standard size is very relative, which depends on human culture or civilization. Arifin in his book "Islamic Education in the Flow of Community Dynamics" states that the formulation of the goals of Islamic education realizes Muslim people who are faithful, pious, and knowledgeable who are able to devote themselves to the opposite with a round attitude and personality surrendering to Him in all aspects of life in order looking for his pleasure. The formulation of the objectives of Islamic education is very relevant to the formulation of national education goals. The formulation of the national education goals is to educate the nation's life and develop Indonesian people as a whole, namely believing people, fearing the Almighty God, noble character, possessing knowledge and skills, physically and mentally healthy, a solid and independent personality and responsibility social and national responsibility (Arifin Muzayin, 2000).

If it is associated with Islamic philosophical philosophy, the curriculum certainly must be integrated (integral) with the teachings of Islam itself. The aim to be achieved by the PAI curriculum is to shape students to become noble, in relation to the nature of human creation. In connection with this Islamic education curriculum, in broad interpretation, the curriculum contains material for lifelong education (long life education), according to the hadith of the Prophet Muhammad.

$$
\text { اطلب العلم من المهدي الي اللهدي }
$$

"Demand knowledge from cradle to grave" (Abdullah Idi, 1999).

Islamic religious education is a conscious and planned effort in preparing students to believe, understand, appreciate, and practice Islamic teachings through guidance, teaching and training activities. So broadly speaking (general) the purpose of Islamic religious education is to improve the faith, understanding, appreciation, and practice of students towards the teachings of Islam, so that he becomes a Muslim human who fears Allah SWT, as well as noble both in personal life, community, nation and state.

The goal is still oriented towards the national mention goals contained in the RI Law. 20 of 2003. The further general objectives of the above PAI are elaborated on the objectives of each educational institution by the current education level.

Also, Islamic religious education as a learning program is directed to:

1. Maintain the faith and loyalty of students,

2. Become the foundation for more diligent study and study of the religious sciences,

3. Encouraging until students to be more critical, creative and innovative,

4. Being a foundation of behaviour in everyday life in the community. Thus not only teaches knowledge in theory but also to be practised or practised in everyday life [building social ethics] (Hamdan, 2014).

From the above understanding that the PAI curriculum aims to increase productivity, creative, innovative, effective in carrying out the faith and loyalty, to improve what students have learned about the science of religion and practised in everyday life. 


\section{PERMENDIKBUD (MINISTERIAL REGULATION) OF ISLAMIC EDUCATION (PAI) CURRICULUM}

Regulation of The Minister of Education and Culture About Curriculum 2013 First Medium School/ Madrasah Tsanawiyah (Permendikbud No.58 tahun 2014).

Pascal 1

1. Curriculum for Junior High School/ Madrasah Tsanawiyah that has been implemented since the 2013/2014 school year is called the 2013 Curriculum for Junior High Schools/ Madrasah Tsanawiyah.

2. The 2013 Middle School/ Madrasah Tsanawiyah curriculum as referred to in paragraph (1) consists of:

a. Basic Curriculum Framework;

b. Curriculum Structure;

c. Syllabus; and

d. Subject Guidelines.

\section{Pascal 2}

The Basic Curriculum Framework as referred to in Article 1 paragraph (2) letter a contains philosophical, sociological, psycho-pedagogical and juridical foundations by the National Education Standards.

\section{Pascal 3}

1. Curriculum structure, as referred to in paragraph (2) letter b is the organisation of Core Competencies, Basic Competencies, learning content, subjects, and learning burdens.

2. Core Competencies in the 2013 Junior High School/ Madrasah Tsanawiyah Curriculum as referred to in paragraph (1) is the level of ability to achieve the Graduate Competency Standards that must be possessed by a junior high school student/ Madrasah Tsanawiyah at each grade level.

3. Core competencies as referred to in paragraph (1) consist of:
a. Spiritual Core Core Competence;
b. Core Competence social attitude;
c. Core knowledge competencies; and
d. Core skills competency.

4. Basic Competency in the 2013 Middle School/ Madrasah Tsanawiyah Curriculum as referred to in paragraph (1) contains the ability and content of learning for subjects in Junior High School/ Madrasah Tsanawiyah which refers to Core Competence.

5. Basic competency as referred to in paragraph (4) is an elaboration of Core Competencies and consists of:

a. Basic competency spiritual attitude; 

b. Competence Basic social attitudes;
c. Basic knowledge competency; and
d. Basic competency skills.

Regulation of The Minister of Education and Culture About The 2013 Curriculum of The Middle School/ Madrasah Aliyah (Permendikbud No.59 tahun 2014).

\section{Pascal 1}

1. The curriculum for high school/madrasah aliyah that has been implemented since the 2013/2014 school year is called the 2013 Curriculum for Senior High Schools / Madrasah Aliyah.

2. 2013 Curriculum High School/ Madrasah Aliyah as referred to in paragraph (1) consists of:
a. Basic Curriculum Framework;
b. Curriculum Structure;
c. Syllabus; and
d. Subject Guidelines.

\section{Pascal 2}

The Basic Curriculum Framework as referred to in Article 1 paragraph (2) letter a contains philosophical, sociological, psycho-pedagogical and juridical foundations by the National Education Standards.

\section{Pasal 3}

1. Curriculum structure, as referred to in Article 1 paragraph (2) letter b is the organisation of Core Competencies, Basic Competencies, learning content, subjects, and learning burdens.

2. Core Competencies in the 2013 Curriculum High School/ Madrasah Aliyah as referred to in paragraph (1) is the level of ability to achieve the Competency Standards of Graduates that must be possessed by an Aliyah High School / Madrasah student at each grade level.

3. Core competencies as referred to in paragraph (1) consist of:
a. Spiritual Core Core Competence;
b. Core Competence social attitude;
c. Core knowledge competencies; and
d. Core skills competency.

4. Basic Competency in 2013 Curriculum High School/ Madrasah Aliyah as referred to in paragraph (1) contains the ability and content of learning for a subject in the Senior High School / Madrasah Aliyah that refers to Core Competence. (5) Basic competency as referred to in paragraph (4) is an elaboration of Core Competencies and consists of:
a. Basic competency spiritual attitude;
b. Competence Basic social attitudes; 

c. Basic knowledge competency; and
d. Basic competency skills.

\section{CHARACTERISTICS OF THE 2013 PAI CURRICULUM MODEL}

The following are the characteristics inherent in K-13 (Curriculum 2013), namely (Mulyasa, 2017):

\section{Realising Character Education}

Character education is the character and primary characteristic of the previous education curriculum. Where in the curriculum, it is demanded how to print students who have good character, morality and good character. However, in the implementation of this curriculum, there are still various skills so that there are multiple criticisms. This competency-based is revised to create a sustainable education system that can educate the nation's life.

\section{Creating Local Insightful Education}

Local insight is one essential thing. However, in reality, the potential and local culture have been neglected and eroded by the strong influence of modern civilisation (Ikhwan, 2017). Religion tends to bring people to forget the noble ideals of their ancestors and the potential they have from within. Soul. That is what drives how the cultivation of local culture in education can be applied. This system will be used in the concept of the 2013 curriculum education system. A system that can thicken local culture which has been forgotten and seems ignored. Therefore, with the 2013 curriculum education system, it is expected that the pillars of the local culture can become inspiration and implementation in community life. Can be an essential feature and become a king in his own country and not extinct swallowed by the times.

3. Creating a cheerful and friendly education

Education is not only a medium of learning. But knowledge is a place to explore all the potential in ourselves. By that, with the education system applied in the 2013 curriculum, it will be expected to be able to explore all the possibilities of students, both academic and non-academic. So in this way, the 2013 syllabus will be applied to a more pleasant, friendly, exciting and competent education. So that in this way, all students' potential and creativity are expected to be exploited quickly and accurately.

The PAI curriculum has characteristics, especially in the form of operational development and implementation in learning (Ikhwan, 2018). These characteristics can be known among others from the way PAI teachers optimize performance in the learning process, management of learning resources, professionalism of educational staff, and highlighting religious goals and akhlaqul karimah, both in teaching goals, material and motion of its implementation (Umar Sidiq, 2018); (Sulaeman, 2015).

Regarding the characteristics of the PAI curriculum, Azyumardi explained that the PAI curriculum has several features, namely (Sayyi, 2017):

1. Emphasis on the search for knowledge, mastery and development of science based on worship to Allah which lasts for life;

2. Practising science based on responsibility to Allah SWT and society; 
3. Recognition of the potential and ability of students to develop in a whole personality;

4. Every seeker of knowledge is seen as a creature of God that needs to be respected and sponsored so that the potential possessed can accumulate well.

Based on the above understanding, the authors conclude that school/madrasah education for the future must have the following characteristics:

1. Religious education, so that graduates of strong faith, from this faith, will be embedded in noble character; Islamic faith education will give graduates the ability to be able to live in a global age that is full of challenges and strict competencies; and ready to overcome challenges and become a successful competition.

2. Active English language education, to be able to communicate and cooperate at the world level

3. Scientific knowledge, to be able to continue their education to a higher level, at the university level it must reach the level of experts who can develop knowledge or be able to do a high level of expertise.

4. Educational work skills of at least one type, so that graduates can find life if they do not work in the formal sector according to their expertise.

\section{DEVELOPMENT OF THE K13 MODEL PAI CURRICULUM}

PAI in K 13 is included in compulsory subjects and changed its name to Islamic Education and Character Education. For a more in-depth and more straightforward understanding of the development of the PAI curriculum for the K 13 model, it is better first to describe the curriculum components (Ikhwan, 2013).

Meanwhile, according to Government Regulation Number 32 of 2013 concerning National Education Standards (SNP), the curriculum is defined as a set of plans and arrangements regarding the purpose, content, and material of learning and the methods used to guide the implementation of learning activities to achieve educational goals. Certain. Thus, the curriculum should be contained in one written document or written plan that includes a statement about the quality that must be possessed by students who follow the curriculum activities (PP RI No.32, Th.2013).

Basically, curriculum development is needed when the current curriculum (current curricula) is deemed ineffective or irrelevant to the demands of the times. So that the impact of each change will affect depending on how much the logical consequences of a change made (M. Tisna Nugraha, 2016).

In implementing a national scale curriculum, it often happens along with the needs of the times. This invites several questions and debates, given this shift has implications for the dynamics of national education. Especially if the changes are carried out abruptly and in a short time without any clear consideration, certainly cause various problems that are sporadic in the formal sectors in responding to changes.

Furthermore, according to Zuhri stated that the development of the curriculum was related to the preparation of all curriculum dimensions starting from the foundation, subject structuring structure, scope, sequence of learning materials, outlines of learning programs, to the development of implementation guidelines. Also, curriculum development is a planning process, producing a tool that is better based on the results of an assessment of the applicable curriculum, so that it can provide better teaching and learning conditions. That is, curriculum development is an activity to produce a new 
curriculum through the preparation of curriculum or the basis of the results of the assessment carried out during a specific period and time (Zuhri, 2012).

Development of PAI curriculum according to at least must pay attention to four components, namely material, objectives, methods (strategies) and evaluation. The four parts according to A. Rifqi Amin in it must contain Islamic teaching values on each component. The four elements must be intertwined integrally as provided in the following picture (a.Rifqi Amin, 2014):

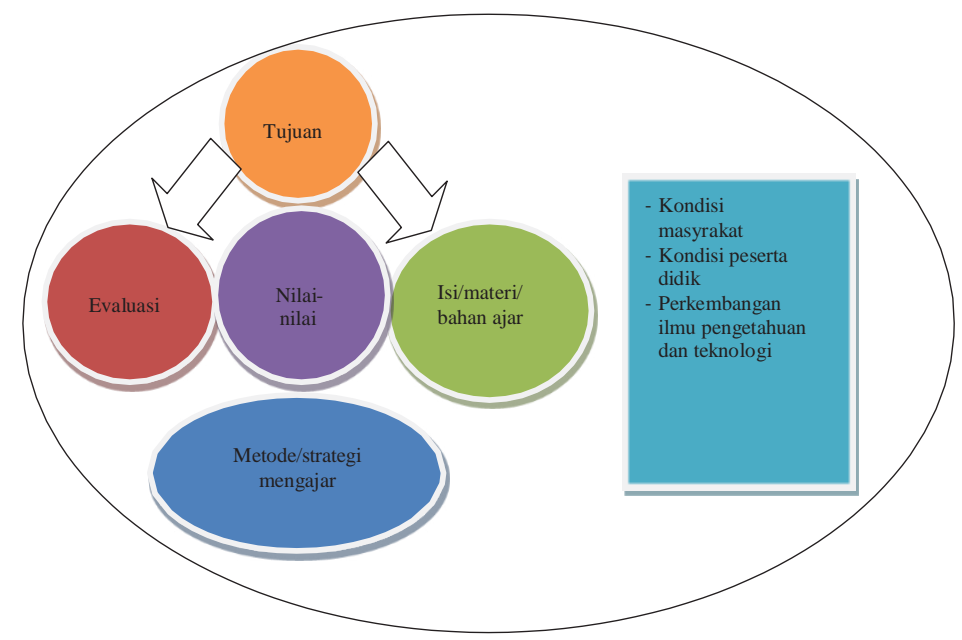

Picture 1. Integral Curriculum Components

From the picture above if it is related to the previous discussion, it can be concluded that the components of PAI curricula are related and related as a form of collaboration in the realization of the PAI curriculum so that it remains relevant to reality, time, community conditions, conditions of students, and conditions of scientific development technology. But what needs to be emphasized is that the curriculum of Islamic Education must be embedded in Islamic values as the main axis that characterizes. Even though such educators continue to strive in curriculum development, especially in PAI material so that PAI learning systems remain attractive, especially for students who have critical reason. straight that one component of the PAI learning system is the PAI curriculum which also consists of several other components, namely goals, materials, methods, and evaluations. While other components of the PAI learning system are educators, students, institutional managers, and learning resources other than educators (b.Rifqi Amin, 2014).

According to Nasution, quoted by Abdullah, there are four components of the curriculum, namely objectives, learning materials, processes, and assessments. Meanwhile, Hasan Langgulung divided the curriculum components into four, namely: the purpose of education, content or content of education, teaching methods, and methods of assessment. Referring to the two opinions above, the presentation of the $\mathrm{K}$ 13 model curriculum development in this paper is described in the components of objectives, contents, processes and assessments.

\section{Component of Purpose}

At $\mathrm{K} \mathrm{13}$, the curriculum objectives component is listed in the Graduate Competency Standard (SKL). SKL is a criterion regarding the qualifications of graduates' ability, which includes attitudes, knowledge and skills. SKL is used as 
the primary reference for the development of content standards, process standards, educational assessment standards, standards for educators and education personnel, standards for facilities and infrastructure, management standards, and financing standards (Supriyono, 2015).

\section{Fill Components}

In the content component, in K 13 there are core competencies and necessary competencies. Skills that were initially derived from subjects turned into subjects developed from competencies.

Hierarchically, Graduates' Competency Standards are used as a reference to establish generic competencies at each Competency Level. This generic competency is then used to determine skills that are specific to each subject. Furthermore, the competence and scope of the material are used to determine Basic Competence in the development of unit-level curriculum and education level. Generic competencies include 3 (three) domains namely attitudes, knowledge and skills. The attitude domain is divided into spiritual beliefs and social attitudes. This sorting is needed to emphasize the importance of the balance of function as a whole human being which includes spiritual aspects and social aspects as mandated in national education goals. Thus, generic competencies consist of 4 (four) dimensions that represent religious attitudes, social attitudes, knowledge and skills, hereinafter referred to as Core Competencies (KI).

Each Competency Level has implications for the demands of the learning and assessment process. Further description of Competency Levels at each level of education according to their achievement in each class will be carried out by the Curriculum Developer. Different levels of competency require learning and assessment with varied focus and emphasis. The higher the Competency Level, the more complex the intensity of learning experiences of students and the learning and assessment process (a.Permendikbud, No.21 Th.2016).

\section{Process Components}

\section{a. Learning Characteristics}

Islamic education methods desired by Muslims are mostly the method of education through the teaching of Islam (the purpose of learning through Islamic teachings) over all fields of science and skills according to Islamic teachings (Nur Uhbiyati, 1997).

To strengthen the scientific, integrated thematic approach (thematic between subjects), and thematic (in a topic) it is necessary to apply discovery/inquiry learning. To encourage the ability of students to produce contextual work, both individually and in groups, it is strongly recommended to use a learning approach that provides problem-based work (project-based learning) (Ikhwan, 2014).

\section{b. Planning}

Learning planning is designed in the form of a Syllabus and Learning Implementation Plan (RPP) that refers to the Content Standard. The syllabus is a reference for preparing the learning framework for each subject matter. The Learning Implementation Plan (RPP) is a plan for face-to-face learning activities for one or more meetings. 
RPP is developed from the syllabus to direct students' learning activities to achieve Basic Competency (KD). Every educator in the education unit is obliged to prepare lesson plans in a complete and systematic manner so that learning takes place interactively, inspiring, fun, challenging, efficient, motivating students to actively participate, and providing sufficient space for initiative, creativity, and independence according to talent, interests and physical and psychological development of students. RPP is prepared based on the $\mathrm{KD}$ or sub-theme, which is held one meeting or more (b.Permendikbud, No.21 Th.2016).

In K 13, the syllabus development was not carried out by the teacher, but it had been prepared by the curriculum development team, both at the central and regional levels. Therefore, the teacher only needs to develop lesson plans based on the teacher's guidebook, student manuals and source books that have all been prepared (b.Mulyasa, 2017).

c. Learning Implementation

1) Allocation of Learning Time

a) SD/MI: 35 minutes,

b) SMP/MTs: 40 minute,

c) SMA/MA: 45 minutes,

d) SMK/MAK: 45 minutes.

2) Study Groups

Table 1

Study Group

\begin{tabular}{|c|l|c|c|}
\hline No & $\begin{array}{c}\text { Education } \\
\text { units }\end{array}$ & $\begin{array}{c}\text { Number of Study } \\
\text { Groups }\end{array}$ & $\begin{array}{c}\text { Maximum Number of } \\
\text { Students Per Study Group }\end{array}$ \\
\hline 1. & SD/MI & $6-24$ & 28 \\
\hline 2. & SMP/MTs & $3-33$ & 32 \\
\hline 3. & SMA/MA & $3-36$ & 36 \\
\hline 4. & SMK & $3-72$ & 36 \\
\hline 5. & SDLB & 6 & 5 \\
\hline 6. & SMPLB & 3 & 8 \\
\hline 7. & SMALB & 3 & 8 \\
\hline
\end{tabular}

3) Learning Implementation

The implementation of learning is an implementation of the RPP covering the Preface, Core and Closing (Yunus, 2014).

a) Introduction: prepare the physical and psychological learners, motivate, review the previous material, link the previous material with the material to be studied, deliver the learning objectives, deliver material coverage.

b) Core activities: The core activities use learning models, learning methods, learning media, and learning resources that are tailored to the characteristics of students and subjects. The selection of integrated and 
scientific thematic and/or thematic approaches and/or inquiry and disclosure (discovery) and/or learning that produce work based problem solving (project-based learning) is adjusted to the characteristics of competency and education level.

c) Closing: Reflection, feedback, follow-up, and informing further learning activities.

Regarding the components of the K 13 process, Mulyasa added the following explanation.

a) The scientific approach consists of several steps, namely: observing, asking, processing, reasoning, presenting, concluding and creating;

b) Learning does not only occur in the classroom, but also the community and school environment;

c) The teacher is not the only source of knowledge;

d) Attitudes are not taught through verbal but through examples and examples (c.Mulyasa, 2017).

\section{In the Assessment Component}

In $\mathrm{K} \mathrm{13}$, assessment is not only about the final results of learning, but also on the learning process. The evaluation of the learning process uses an authentic assessment approach that assesses the readiness of students, processes, and learning outcomes as a whole. Authentic here also means measuring all attitudes, knowledge and skills competencies based on methods and results.

Evaluation of the learning process is carried out during the learning process using tools: observation sheets, peer questionnaires, recordings, anecdotal notes, and reflections. Learning outcomes assessment is carried out during the learning process and at the end of the learning, unit using methods and tools: oral / deed tests, and written tests. The final evaluation results are obtained from a combination of process evaluation and the evaluation of learning outcomes (Soleh Hidayat, 2013).

\section{CONCLUSION}

From the description of the material above, it can be concluded that the development of an Islamic religious education curriculum (PAI) is an activity to produce a PAI curriculum and a process that links one component to another to create a better Islamic education curriculum (PAI). The PAI curriculum aims to increase productivity, creative, innovative, effective in carrying out faith and loyalty, to improve what students have learned about the science of religion and practised in everyday life.

The PAI Curriculum function is an activity to describe or deepen the elements in PAI learning that build a PAI curriculum, which contains PAI values in each component. The curriculum component must consist of at least four parts, namely objectives, contents, processes and assessments. Therefore from the previous discussion about PAI learning, specifically for the PAI curriculum in it must contain the values of Islamic teachings on each component, which of course must be mutually related. 


\section{REFERENCES}

[1] Arifin, Syamsul. 2008. "Pelembagaan Multikulturalisme Melalui Metode Living Values di Madrasah: Sebuah Eksplorasi Awal", dalam jurnal Edukasi, Volume 6, Nomor 2, April-Juni 2008. Lili Hidayati, Kurikulum 2013 dan Arah Baru Pendidikan Agama Islam, STAI Al-Hikmah Benda Brebes, Insania, Vol. 19, No. 1, Januari - Juni 2014.

[2] Amin, A. Rifqi. Sistem Pembelajaran Pendidikan Agama Islam Pada Perguruan Tinggi Umum.Yogyakarta:Deepublish, 2014.

[3] Ach. Sayyi, Modernisasi Kurikulum Pendidikan Islam DalamPerspektif Azyumardi Azra, Sekolah Tinggi Agama Islam Al-Khairat Pamekasan Tadris, Volume. 12, Nomor 1, Juni 2017.

[4] Abidin Yunus, Desain Pembeljaran dalam Konteks Kurikulum 2013, Bandung: PT Refika Aditama, 2014.

[5] Abdulloh, Pengembangan Kurikulum Teori dan Praktek, Yogyakarta: Ar-ruzz Media, 2010.

[6] Abdul Majid dan Dian Andayani, Pendidikan Agama Islam Berbasis Kompetensi, Bandung: PT.Remaja Rosdakarya, 2005.

[7] Darwis, Umar Ahmad. 2015. Landasan Konseptual Pengembangan Kurikulum PAI

[8] Daradjat, Zakiah, Peranan Agama dalam Kesehatan Mental, Jakarta: Gunung Agung, 2002.

[9] DaradjatZakiah dkk, Ilmu Pendidikan Islam Jakarta: Bumi Aksara, 2008.

[10] Dakir, Perencanaan dan Pengembangan Kurikulum, Jakarta: Rineka Cipta, 2010.

[11] Mulyasa, Pengembangan dan Implementasi Kurikulum 2013, Bandung: PT Remaja Rosdakarya, 2017.

[12] Hamdan, Pengembangan dan Pembinanaan KurikulumTeori dan Praktek Kurikulum PAI, Banjarmasin: IAIN ANTASARI PRESS 2014.

[13] Hamid Hamdani, Pengembangan Kurikulum Pendidikan, Bandung: CV Pustaka Setia, 2012.

[14] Hidayat Sholeh, Pengembangan Kurikulum Baru, Bandung: PT Remaja Rosdakarya, 2013.

[15] Hidayati Lili, Kurikulum 2013 dan Arah Baru Pendidikan Agama Islam, STAI Al-Hikmah Benda Brebes, Insania, Vol. 19, No. 1, Januari - Juni 2014.

[16] Idi, Abdullah. Pengembangan Kurikulum: Teori dan Praktek. Yogyakarta: ArRuzz Media, 2007.

[17] Idi, Abdullah Idi. Pengembangan Kurikulum Teori dan Praktek. Jakarta: Gaya Media Pratama, 1999.

[18] Langgulung Hasan, Peralihan Paradigma Pendidikan Islam dan Sains Sosial, Jakarta: Gaya Media Pratama, 2002.

[19] Muhaimin, Pengembangan Kurikulum Pendidikan Agama Islam; di Sekolah, Madrasah, dan Perguruan Tinggi, Jakarta: PT. Raja Grafindo Persada, 2005.

[20] Muzayin Arifin, Pendidikan Islam Dalam Arus Dinamika Masyarakat, Jakarta: PT Golde Terayon Press, 2000.

[21] Muhamad Tisna Nugraha, Pengembangan Model Kurikulum Pendidikan Agama Islam (PAI) Menuju Masyarakat Ekonomi Asean (MEA), Dosen Jurusan PGMI Fakultas Tarbiyah dan Ilmu Keguruan (FTIK), Institut Agama Islam Negeri (IAIN) Pontianak, Jurnal At-Turats Vol. 10 No. 1 tahun 2016.

[22] Nasution. 2006. Asas-asas Kurikulum. Jakarta: Bumi Aksara

[23] Nuraini \& Muhtarima, M. (2016). IMPLEMENTASI KURIKULUM 2013 PADA MATA PELAJARAN PENDIDIKAN AGAMA ISLAM DI SD MUHAMMADIYAH TERPADU 
PONOROGO. Istawa: Jurnal Pendidikan Islam, $1(2), \quad 52 \quad-\quad 80$. doi:http://dx.doi.org/10.24269/ijpi.v1i2.167

[24] Permendikbud No. 58 tahun 2014 tentang Kurikulum PAI SMP

[25] Permendikbud No. 59 tahun 2014 tentang Kurikulum PAI SMA

[26] Peraturan Pemerintah Republik Indonesia Nomor 32 Tahun 2013 Tentang Perubahan Atas Peraturan Pemerintah Nomor 19 Tahun 2005 Tentang Standar Nasional Pendidikan.

[27] Permendikbud Th. 2016 No. 021, Tentang Standar Isi Pendidikan Dasar dan Menengah -Lampiran.

[28] Soetopo, Hendayat Soetopo dan Wast Soenanto. 1993. Pembinaan dan Pengembangan Kurikulum. Jakarta: Bumi Aksara

[29] Subandiah, Pengembangan dan Inovasi Kurikulum, Jakarta: PT, Raja Grafindo Persada, 1993

[30] Supriyono,Studi Analisis Konsep Pengembangan Kurikulum 2013; Sebuah Tantangan Bagi Pendidikan Islam, STIT Muh. Kendal, JURNAL DIDAKTIKA ISLAMIKA Volume 5 Nomor 1 Pebruari 2015.

[31] Sulaeman,A, Pengembangan Kurikulum 2013 Dalam Paradigma Pembelajaran Kontemporer, Dosen Universitas Muhammadiyah Purwokerto,ISLAMADINA, Volume XIV , No. 1 , Maret 2015.

[32] Toto, Suharto. Filsafat Pendidikan Islam. Yogyakarta: Ar-Ruzz Media, 2011.

[33] Usmar, Ali, Model-Model Pengembangan Kurikulum dalam Proses Kegiatan Belajar, Jurnal An-Nahdhah, Vol. 11 No. 2 Juli - Desember 2017.

[34] Uhbiyati Nur, Ilmu Pendidikan Islam (IPI), Bandung: Pustaka Setia, 1997.

[35] Wina Sanjaya, Kurikulum dan Pembelajaran, Jakarta: Kencana, 2011.

[36] Zuhri.Convergentive Design: Kurikulum Pendidikan Pesanren (Konsepsi dan Aplikasinya). Yogyakarta: Deepublish, 2012.

[37] Afiful Ikhwan. (2017). Development Of Quality Management Islamic Education In Islamic Boarding School (Case Study Madrasah Aliyah Ash Sholihin). AlHayat: Journal of Islamic Education, 01(01), 1-27.

[38] Ikhwan, A. (2013). Model Organisasi Ideal Bagi Perguruan Tinggi Islam di Indonesia. Ta'allum: Jurnal Pendidikan Islam, 1(1), 29-36. Retrieved from http://ejournal.iain-tulungagung.ac.id/index.php/taalum/article/view/537

[39] Ikhwan, A. (2014). Integrasi Pendidikan Islami (Nilai-Nilai Islami dalam Pembelajaran). Ta'allum: Jurnal Pendidikan Islam, 2(2), 184. https://doi.org/10.21274/taalum.2014.2.2.179-194

[40] Ikhwan, A. (2017). Kajian Sosio-Historis Pendidikan Islam Indonesia Era Reformasi. Edukasi: Jurnal Pendidikan Islam, 5(1), 17. Retrieved from http://ejournal.staim-tulungagung.ac.id/index.php/EDUKASI/article/view/268

[41] Ikhwan, A. (2018). MANAGEMENT OF LEARNING ASSESSMENT USING CURRICULUM 2013 (CASE STUDY IN ISLAMIC PRIMARY SCHOOL (MI) MUHAMMADIYAH 5 WONOASRI PONOROGO - EAST JAVA INDONESIA). MUADDIB: Studi Kependidikan Dan Keislaman, 08(02), 108123. https://doi.org/10.24269/muaddib.v8i2.1422

[42] Musyarapah. (2017). The Role of Progressive Philosophy in the Curriculum Based on John Dewey's Theory. Al-Hayat: Journal of Islamic Education, 01(01), $1-8$.

[43] Nurhadi. (2018). Manajemen Penilaian Pembelajaran Menggunakan K13. AlHayat: Journal of Islamic Education, 02(01), 1-16. 
[44] Umar Sidiq, L. I. (2018). Inclusive Curriculum Education Modification Management (Case Study at Ponorogo National Immersion Primary School). AlHayat: Journal of Islamic Education, 02(02), 1-11.

[45] Wawan Kusnawan. (2019). Inconsistency of Curriculum of Education in Indonesia, 4(1). https://doi.org/10.24269/ijpi.v4i1.1667 